\title{
Protein utilization responses of growing pigs to supplemental lysine as liquid versus crystalline form in barley-barley protein diet
}

\begin{abstract}
MATTI NÄSI
NÄSI, M . 1992. Protein utilization responses of growing pigs to supplemental lysine as liquid versus crystalline form in barley-barley protein diet. Agric. Sci. Finl. 1: 215-223. (Univ. Helsinki, Dept. Anim. Sci., SF-00710 Helsinki, Finland.)

The study examined the influence of increasing dietary supplements of liquid compared to crystalline lysine on nitrogen $(\mathrm{N})$ balance and protein utilization in growing pigs $(30-100 \mathrm{~kg} \mathrm{LW})$ in a $8 * 8$ Latin square. Eight isonitrogenous diets with $160 \mathrm{~g}$ $\mathrm{CP} / \mathrm{kg}$ were formulated from barley and barley protein supplemented with the two lysine sources at levels of none, 1,2 and $3 \mathrm{~g} / \mathrm{kg}$ to provide $5.5,6.5,7.5$ and $8.5 \mathrm{~g} / \mathrm{kg}$ total dietary lysine. Barley-SBM served as a contol diet. The dietary lysine concentration had substantial effect on $\mathrm{N}$ retention and metabolism. The lysine supplements to the cereal-based diet with a low lysine content, $5.5 \mathrm{~g} / \mathrm{kg}$, significantly improved $\mathrm{N}$ retention, decreased urinary- $\mathrm{N}$ excretion and enhanced protein utilization and daily gain. There was a linear response of $\mathrm{N}$-retention, urinary- $\mathrm{N}$ and urea-N excretion and apparent biological value $(\mathrm{P}<0.001)$ to lysine supplementation level. As the lysine concentration was gradually increased, the efficiency of $\mathrm{N}$ retention in relation to $\mathrm{N}$ intake and absorbed $\mathrm{N}$ increased linearily. No difference was found in $\mathrm{N}$ balance parameters between the two lysine sources, liquid vs. crystalline form being equal in their response. Pigs fed the SBM-diet compared to the barley protein diet fortified with lysine did not differ in response of $\mathrm{N}$ retention and protein utilization, but SBM lead to lower urinary- $\mathrm{N}$ excretion. $\mathrm{N}$ retention, urinary- $\mathrm{N}$ excretion and biological value as parameters for protein utilization showed lower variability (CV 0.08-0.10) compared to urinary urea-N excretion (CV 0.20). Regression coefficients of responses of protein utilization to liquid lysine were overall lower than those to crystalline lysine.
\end{abstract}

Key words: lysine, pure amino acid, protein, nitrogen balance, pig

\section{Introduction}

A feed protein seldom contains an amino acid composition which is similar to the requirements of the growing pig. Lysine is generally considered as the first limiting amino acid in conventional cereal based diets for pig (FULLER et al. 1979, NÄSI 1989). The cereal based pig diets are supplemented with protein sources to increase the total protein content and to counteract any essential amino acid deficiency. When the diets are supplemented with protein concentrate, with the aim of reaching levels of lysine optimal for protein synthesis, the amounts of other amino acids may become excessive. Amino acids surplus to the pig's requirement are catabolized causing nitrogen $(\mathrm{N})$ and urea losses in urine. Increasing amounts of digestible crude protein (CP) in the diet enhance the energy loss in the 
urine, decrease metabolizable energy (ME) in relation to digestible energy and also decrease the efficiency of utilization of ME. Thus the catabolism of excess protein reduces net energy available for pig growth (JUST 1982).

An ideal protein for pig growth can be described as one which supplies the optimum balance of essential amino acids together with sufficient $\mathrm{N}$ for the synthesis of non-essential amino acids. Proteins of high nutritional value for pig tend to resemble the lean tissue in their amino acid composition and are close to the dietary amino acid pattern which leads to the highest utilization of the dietary protein (ARC 1981, WANG and FULLER 1989). L-lysine and DL-methionine are two amino acids which are commonly used in pig diets to replace or supplement natural intact protein sources of lysine and methionine. The purpose of using synthetic amino acids in the pig diets is to reduce CP levels and cut the cost of the diets without deteriorating pig performances.

Cereal protein after starch and ethanol process (NÄsI 1988) has a low quality of protein (LINKO et al. 1989) considering the degree to which the composition of the absorbed amino acids is in accordance with the balance that is required by the pig (NÄsI 1989). The amino acid composition of barley protein can be improved as a protein souce for pig feeding by fortification with pure lysine (NÄSI 1989). Barley feed fractions to the pig farms are delivered commonly in a liquid form, which reduces the feed cost due to dehydration and eliminates deterioration of the protein quality in drying process. Lysine supplementation to wet barley protein could be employed as liquid form, which would reduce the production costs of the lysine process and would avoid to a greater extent the environmental problems of waste waters in crystallization and purification of crystalline lysine.

The present paper reports an experiment which was conducted to determine the efficiency of the liquid lysine product compared to crystalline form in protein utilization of growing pigs as affected by the dietary lysine concentration in a barley-barley protein lysine deficient diet.

\section{Material and methods}

Eight dietary treatments were used in comparisons of the lysine forms and levels of supply as outlined in Table 1. The diets were formulated isonitrogenous to supply $160 \mathrm{~g} \mathrm{CP}$ per kg barley meal based feed mixture. Protein supplementation was made with barley protein derived from integrated starchethanol production (Alko Ltd. Koskenkorva) according to the process described by NÄsI (1988). As the (positive) control diet served barley supplemented with soybean meal to yield equal protein supply. The chemical composition of the feed ingredients are presented in Table 2. Lysine supplementation of the diets $(1,2$, and $3 \mathrm{~g}$ pure lysine/ $\mathrm{kg}$ feed mixture) was made using a liquid product form in fermentation by Brevibacterium flavum, strain V-5, emloying the technology developed at the August Kirchenstein Institute of Microbiology of the Latvian Academy of Sciences, Riga (BEKER et al. 1971). The culture liquid was sterilized and dehydrated in a vacuum-vapour evaporator up to a DM content of $400 \mathrm{~g} / \mathrm{kg}$. This product was stabilized by adding hydrochloric acid to $\mathrm{pH} \mathrm{5.1}$. The crystalline lysine was a commercial product, Llysine monohydrochloride (Eurolysine).

The experiment was designed as a $8 \times 8$ balanced Latin square with growing pigs of castrated males (Landrace $\mathrm{x}$ Large White) with initial weight of 30.4 (SE 0.39) $\mathrm{kg}$ and final weight of 101.3 (SE $0.41) \mathrm{kg}$. The pigs were kept during the whole experiment in metal metabolism cages equipped with collection trays allowing separate collection of faeces and urine. Each period comprised 5 days of adjustment and 5 days of total collection of faeces and urine. The pigs were fed twice daily according to a restricted feeding regime and their diets were adequately fortified with minerals and vitamins (SALo et al. 1982). The average daily DM intake was kept at $93 \mathrm{~g} / \mathrm{kg} \mathrm{W}^{0.75}$. The details of the procedure are the same as described by NÄSI (1984). Amino acids in liquid lysine and barley protein were determined by high-performance liquid chromatography. All animals completed the experiment successfully and the average daily 
Table 1. The outline of the experimental design and diet composition.

\begin{tabular}{lrrrrrrrr}
\hline DIET No & 1 & 2 & 3 & 4 & 5 & 6 & 7 & 8 \\
\hline Barley, g/kg & 867 & 786 & 786 & 786 & 786 & 786 & 786 & 786 \\
& & & & & & & & \\
Protein supplement & 133 & - & - & - & - & - & - & - \\
Soybean meal, g/kg & - & 214 & 214 & 214 & 214 & 214 & 214 & 214 \\
Barley protein, g/kg & 160 & 160 & 160 & 160 & 160 & 160 & 160 & 160 \\
Total protein supply, g/kg & & & & & & & - & - \\
Lysine supplement & - & - & 1.0 & 2.0 & 3.0 & - & - \\
Liquid lysine, g/kg & - & - & - & - & - & 1.0 & 2.0 & 3.0 \\
Crystalline lysine, g/kg & 7.4 & 5.5 & 6.5 & 7.5 & 8.5 & 6.5 & 7.5 & 8.5 \\
Total lysine supply, g/kg & & & & & & & & \\
\hline
\end{tabular}

Table 2. The chemical composition of the experimental feeds.

\begin{tabular}{|c|c|c|c|c|c|}
\hline $\begin{array}{l}\text { Feedstuff } \\
\text { Composition }\end{array}$ & Barley & $\begin{array}{l}\text { Barley } \\
\text { protein }\end{array}$ & $\begin{array}{l}\text { Soybean } \\
\text { meal }\end{array}$ & $\begin{array}{l}\text { Liquid } \\
\text { lysine }\end{array}$ & $\begin{array}{l}\text { Crystalline } \\
\text { lysine }\end{array}$ \\
\hline Dry matter, $\mathrm{g} / \mathrm{kg}$ & 883 & 915 & 877 & 401 & 993 \\
\hline Ash, g/kg DM & 28 & 31 & 69 & 146 & 1 \\
\hline Crude protein " & 133 & 352 & 488 & 604 & 822 \\
\hline Ether extract " & 35 & 60 & 38 & 1 & - \\
\hline Crude fibre " & 51 & 20 & 70 & - & - \\
\hline Total sugars " & & & 79 & & \\
\hline Amino acids & & $\mathrm{g} / 160 \mathrm{~g} \mathrm{~N}$ & & $\mathrm{~g} / \mathrm{kg}$ & $\mathrm{g} / \mathrm{kg}$ \\
\hline Lysine & & 30 & & 67.9 & 800 \\
\hline Threonine & & 29 & & 0.1 & \\
\hline Methionine+cystine & & 31 & & - & \\
\hline Histidine & & 20 & & 0.5 & \\
\hline Leucine & & 65 & & 0.3 & \\
\hline Isoleucine & & 55 & & 0.3 & \\
\hline Phenylalanine & & 56 & & - & \\
\hline Arginine & & 43 & & 0.2 & \\
\hline
\end{tabular}

weight gain during the entire experiment was $814 \mathrm{~g}$.

Pig response to graded levels of the supplemental lysine of two sources was assessed in terms of $\mathrm{N}$ balance, urinary- $\mathrm{N}$ and urea excretion, biological value and daily gain. The results were analysed by analysis of variance for Latin Square experiments and linear and quadratic functions were fitted to describe the response of lysine supplementation. The sums of squares for treatment effect were further separated into single degrees of freedom for comparisons of the dietary treatments (SNEDECOR and COCHRAN 1967).

\section{Results and discussion}

The liquid lysine product contained $67.9 \mathrm{~g} / \mathrm{kg}$ pure lysine and by adding to the diet one gram of lysine supplied at the same time $0.56 \mathrm{~g} \mathrm{~N}$ which is shown as a small increase of $\mathrm{N}$ supply in the diets (Table 3 ). The supply of other amino acids to the diet by adding liquid lysine was negligible due to the low 
concentrations of these (Table 2). The average daily DM intake was $2013 \mathrm{~g}$, increasing at the beginning of the experiment from $1388 \mathrm{~g}$ to $2617 \mathrm{~g}$ at the end, averaging $93 \mathrm{~g} / \mathrm{W}^{0.75} / \mathrm{d}$ during the trial. Refusals of the diet were negligible. Organic matter digestibility of the diets was on average 0.852 with the coefficient of variation (CV) being 0.0088 . Average CP digestibility of the diets increased from
0.809 to $0.862(\mathrm{P}<0.001)$ during the trial, showing only a very small variation between the diets. The CV of CP-digestibility was as low as 0.013 , indicating a very high precision of the experimental techniques.

Lysine concentration in feed protein was calculated to be $46,34,41,47$ and $53 \mathrm{~g} / \mathrm{kg}$ protein in diets with SBM addition, without lysine supple-

Table 3. The effect of lysine supplementation on the protein metabolism in pigs.

\begin{tabular}{|c|c|c|c|c|c|c|c|c|c|}
\hline DIET No & 1 & 2 & 3 & 4 & 5 & 6 & 7 & 8 & SEM \\
\hline Prot.supplement & SBM & BP & BP & BP & BP & BP & BP & BP & \\
\hline Lysine suppl.g & - & - & LL 1 & LL 2 & LL 3 & CL 1 & CL 2 & CL 3 & \\
\hline Lysine, $\mathrm{g} / \mathrm{kg}$ & 7.4 & 5.5 & 6.5 & 7.5 & 8.5 & 6.5 & 7.5 & 8.5 & \\
\hline $\mathrm{N}$ intake, $\mathrm{g} / \mathrm{d}$ & 55.7 & 56.2 & 57.5 & 58.7 & 59.8 & 56.3 & 56.7 & 57.3 & 0.188 \\
\hline $\mathrm{N}$ faeces, g/d & 9.4 & 9.6 & 9.8 & 10.0 & 10.1 & 9.2 & 9.8 & 9.3 & 0.237 \\
\hline $\mathrm{N}$ absorbed, g/d & 46.2 & 46.6 & 47.8 & 48.6 & 49.8 & 47.1 & 47.0 & 48.0 & 0.254 \\
\hline $\mathrm{N}$ digestibility & 0.825 & 0.826 & 0.826 & 0.823 & 0.827 & 0.833 & 0.825 & 0.828 & 0.0039 \\
\hline $\mathrm{N}$ in urine, $\mathrm{g} / \mathrm{d}$ & 19.3 & 24.7 & 23.4 & 22.9 & 21.1 & 22.6 & 21.9 & 19.7 & 0.844 \\
\hline Urea-N, g/d & 17.7 & 20.5 & 20.9 & 19.8 & 16.5 & 19.9 & 18.6 & 16.5 & 1.390 \\
\hline Urea-N/tot.urinary- $\mathrm{N}$ & 0.776 & 0.839 & 0.764 & 0.850 & 0.760 & 0.758 & 0.857 & 0.706 & 0.067 \\
\hline $\mathrm{N}$ retained, $\mathrm{g}$ & 26.9 & 22.0 & 24.4 & 25.7 & 28.7 & 24.5 & 25.9 & 28.3 & 0.858 \\
\hline - of intake & 0.478 & 0.385 & 0.425 & 0.442 & 0.480 & 0.431 & 0.442 & 0.492 & 0.015 \\
\hline - of absorption & 0.579 & 0.466 & 0.515 & 0.539 & 0.581 & 0.518 & 0.536 & 0.590 & 0.018 \\
\hline - g/kg W0.75 & 1.23 & 1.00 & 1.14 & 1.21 & 1.34 & 1.13 & 1.17 & 1.30 & 0.041 \\
\hline Biological value & 0.647 & 0.540 & 0.585 & 0.606 & 0.645 & 0.588 & 0.606 & 0.656 & 0.017 \\
\hline Daily gain, g/d & 808 & 682 & 781 & 859 & 904 & 731 & 815 & 927 & 44.62 \\
\hline
\end{tabular}

\section{Statistical significance of effect}

\begin{tabular}{|c|c|c|c|c|c|}
\hline & $\begin{array}{l}\text { Lysine } \\
\text { Linear }\end{array}$ & $\begin{array}{l}\text { lementation } \\
\text { Quadratic }\end{array}$ & $\begin{array}{l}\text { Lysine form } \\
\text { Liquid vs. } \\
\text { crystalline }\end{array}$ & $\begin{array}{l}\text { SBM vs. } \\
\text { lysine } \\
\text { supplement }\end{array}$ & $\begin{array}{l}\text { Barley prot } \\
\text { vs. lysine } \\
\text { supplement }\end{array}$ \\
\hline $\mathrm{N}$ intake, $\mathrm{g} / \mathrm{d}$ & $* * *$ & NS & $* * *$ & $* * *$ & $* * *$ \\
\hline $\mathrm{N}$ faeces, $\mathrm{g} / \mathrm{d}$ & NS & NS & ** & NS & NS \\
\hline $\mathrm{N}$ absorbed, g/d & $* * *$ & NS & $* * *$ & $* * *$ & $* * *$ \\
\hline $\mathrm{N}$ digestibility & NS & NS & NS & NS & NS \\
\hline $\mathrm{N}$ in urine, $\mathrm{g} / \mathrm{d}$ & $* *$ & NS & NS & $* *$ & $* *$ \\
\hline Urea-N, g/d & $* *$ & NS & NS & NS & NS \\
\hline Urea-N/tot.urinary- $\mathrm{N}$ & NS & NS & NS & NS & NS \\
\hline $\mathrm{N}$ retained, $\mathrm{g}$ & $* * *$ & NS & NS & NS & $* * *$ \\
\hline - of intake & $* * *$ & NS & NS & NS & $* * *$ \\
\hline - of absorption & $* * *$ & NS & NS & NS & $* * *$ \\
\hline$-\mathrm{g} / \mathrm{kg}$ W0.75 & $* * *$ & NS & NS & NS & $* * *$ \\
\hline Biological value & $* * *$ & NS & NS & NS & $* *$ \\
\hline Daily gain, g/d & $* * *$ & NS & NS & NS & $* *$ \\
\hline
\end{tabular}

$\mathrm{SEM}=$ standard error of the means; significance: $\mathrm{NS}=$ non-significant; ${ }^{* *}(\mathrm{P}<0.01),{ }^{* * *}(\mathrm{P}<0.001)$. 
mentation and with 1,2 , and $3 \mathrm{~g}$ pure lysine / $\mathrm{kg}$, respectively. The diets containing lysine 5.5-8.5 $\mathrm{g} / \mathrm{kg}$ supplied total dietary lysine from 8.3 to 24.7 $\mathrm{g} / \mathrm{d}$ during the experimental period and averaged $12.1,14.3,16.5$ and $18.7 \mathrm{~g} / \mathrm{d}$ for diets with different lysine concentrations.

The results of the $\mathrm{N}$ balance and various calculated parameters of protein utilization are shown in Table 3 . The results indicate that dietary lysine concentration had a substantial effect on nitrogen retention and metabolism. Lysine supplementation in barley-barley protein diet with dietary protein concentration $(160 \mathrm{~g} / \mathrm{kg})$ according to the requirement of growing pig, but insufficient for lysine requirements $(5.5 \mathrm{~g} / \mathrm{kg})$, improved significantly $(\mathrm{P}<0.001) \mathrm{N}$ retention and decreased urinary $\mathrm{N}$ excretion and enhanced protein utilization and also daily gain. There was a linear response of $\mathrm{N}$ retention, urinary- $\mathrm{N}$ and urea- $\mathrm{N}$ excetion and apparent biological values $(\mathrm{P}<0.001)$ to lysine supplementation. The efficiency of $\mathrm{N}$ retention in relation to $\mathrm{N}$ intake and absorbed $\mathrm{N}$ increased linearily with gradually increasing lysine concentration. No difference was found in $\mathrm{N}$ balance between the two lysine sources; liquid versus crystralline form being equal in their response $(\mathrm{P}>0.05)$.

Soybean meal as a lysine supplement compared to the pure lysine supplementation for equal dietary supply did not differ in response of $\mathrm{N}$ retention and protein utilization $(\mathrm{P}>0.05)$, but lead to lower urinary-N excretion $(\mathrm{P}<0.01)$ and tended to achieve a little higher $\mathrm{N}$ retention in relation to $\mathrm{N}$ intake and biological value $(\mathrm{P}<0.06)$. The observation is similar to the previous study in which soybean meal was isonitrogenously replaced by barley protein fortified with lysine (NÄSI 1989). Since the threonine and sulphur-containing amino acid contents of the diets were marginally low, it is possibile that these amino acids could have become the limiting factors on addition of lysine. The fortification of the diet further with methionine and threonine did not have any response in the trial conducted by NÄSI (1989) so that lysine was the limiting amino acid here, in accordance with the observations of replacement studies by Low et al. (1980) and Fuller et al. (1986). Contrary to these results, however, FULLER et al. (1979) found improvements of protein utilization with threonine supplementations to barley diets.

Nitrogen retention in this trial was on average $1.20 \mathrm{~g} / \mathrm{kgW}^{0.75} / \mathrm{d}$ (CV 0.095) showing the highest value (1.34) in the middle of the trial and lowest value at the end (1.10). The curve for nitrogen retention in relation to the live weight $(30-100 \mathrm{~kg})$ at different periods is shown in Figure 1. Similar retentions have been noted by THORBEK et al. (1984) for pigs at $25-80 \mathrm{~kg}$ live weight (1.20 $\left.\mathrm{g} / \mathrm{kgW}^{0.75} / \mathrm{d}\right)$ but much lower in heavier pigs $(0.80$ $\mathrm{g} / \mathrm{kgW}^{0.75} / \mathrm{d}$ ). BERSCHAUER et al. (1983) gave wider values of $\mathrm{N}$-retention $0.46-1.85 \mathrm{~g} / \mathrm{kgW}^{0.75} / \mathrm{d}$. The regression equations for $\mathrm{N}$ retention $\mathrm{g} / \mathrm{kgW}^{0.75} / \mathrm{d}$ as a function of lysine supplementation were

$1.012(\mathrm{SE} 0.0307)+0.092(\mathrm{SE} 0.0164) * \mathrm{X}, \mathrm{R}^{2}=$ 0.628

(where $\mathrm{X}=$ suppl. of lysine $\mathrm{g} / \mathrm{kg}$ ) for crystalline lysine and

$$
1.012(\operatorname{SE} 0.0389)+0.108(\operatorname{SE~} 0.0208) * \mathrm{X}, \mathrm{R}^{2}=
$$
0.457

for liquid lysine source. The regression equation relating N-retention to dietary lysine supplementation indicates that lysine was used with a constant efficiency up to a supply of $8.5 \mathrm{~g} / \mathrm{kg}$. The response of daily gains of the pigs was in accordance with the N-retention results indicating that nitrogen balance can reasonably explain the protein accretion in the body.

Lysine supplementation of $1 \mathrm{~g} / \mathrm{kg}$ feed achieved 0.1 increase in $\mathrm{N}$ retention in this study. Low and PitTMAn (1979) found $\mathrm{N}$ retention to improve significantly by 0.106 in response to 0.2 increase of extra lysine, total lysine from 7.0 to $8.4 \mathrm{~g} / \mathrm{kg}$, but further supplementation was of no benefit. An almost similar response to $\mathrm{N}$ retention as in the present study has been found in boars when lysine was supplemented 1.5 and $3.0 \mathrm{~g} / \mathrm{kg}$ (total lysine 4.7-7.7 $\mathrm{g} / \mathrm{kg}$ ). However, in barrows, only supplements up to $1.5 \mathrm{~g} / \mathrm{kg}$ improved retention (WILLIAMS et al. 1984). The genetical potential of the pigs causes a large variation in this respect. In the 
present experiment increasing increments of lysine to $8.5 \mathrm{~g} / \mathrm{kg}$ of the diet did not reach a plateau so that the inflection point is at a higher concentration of lysine. The present observations of the response of protein utilization to supplemental lysine are in good agreement with the results given by FULLER et al. (1974) where it was found that a minimum urinary $\mathrm{N}$ excretion was obtained when L-lysine was added to barley at the rate of $3.6 \mathrm{~g} / \mathrm{kg}$. Further additions of lysine, methionine, isoleucine or tryptophan were without effect but additon of threonine reduced $\mathrm{N}$ excretion substantially, demonstrating it to be the second limiting amino acid.

Nitrogen retention in relation to absorbed $\mathrm{N}$ was low $(0.466)$ in pigs fed diet, in which protein was provided by cereal protein only. Although barley protein derived in the starch ethanol process has a high digestibility of crude protein, 0.92 (NÄSI 1989), its potential as a protein source is rather low, because it is composed of the storage protein fractions of the seed having a low unbalanced lysine content (30-35 g/kg protein) (LinKo et al. 1989). Lysine supplementation improved the value up to 0.59 , which is a similar value as that in a diet supplemented by lysine from soybean meal. Equal efficiencies of protein utilization have also been reported by THORBEK et al. (1984) in pigs on barley soybean diets. Protein utilization expressed as the ratio of retained $\mathrm{N}$ to absorbed $\mathrm{N}$ as function of lysine supplementation were

$0.469(\mathrm{SE} 0.0132)+0.039(\mathrm{SE} 0.0071) * \mathrm{X}, \mathrm{R}^{2}=$ 0.583

(where $\mathrm{X}=$ suppl. of lysine $\mathrm{g} / \mathrm{kg}$ ) for crystalline lysine and

$0.470(\operatorname{SE~} 0.0147)+0.037(\operatorname{SE~} 0.0079) * \mathrm{X}, \mathrm{R}^{2}=$ 0.405

for liquid lysine.

The response of efficiency of $\mathrm{N}$ retention in relation to absorbed $\mathrm{N}$ to supplemental lysine during the course of the experiment is shown in Figure 1. The values decreased with the development of the pig and with diets having higher lysine concentration. This is in line with the data presented by THORBEK et al. (1984), who found 0.16 lower efficiency in pigs $80-120 \mathrm{~kg}$ live weight compared to pigs weighing $25-80 \mathrm{~kg}$. Under practical conditions growing pigs retain about 0.45 of $\mathrm{N}$ fed with typical diets based on barley and SBM. Studies with growing gilts by FULLER et al. (1979) have shown that supplementation of barley diet with lysine and threonine increased the BV of barley protein from 0.51 to 0.86 while histidine supplement further increased the BV to 0.93 . The highest efficiency of $\mathrm{N}$ retention was achieved with diets having a ratio of at least 45:55 between the essential and the non essential amino acids. This included ( $\mathrm{g} / 16 \mathrm{~g} \mathrm{~N})$ lysine 6.5 , threonine 4.7 , valine 4.9 , methinine+cystine 4.1 , isoleucine 3.9 , leucine 7.2, phenylalanine+tyrosine 7.8 and tryptofan 1.2 (WANG and FULLER 1989). In the present study lysine concentrations in feed protein were from as low as $34 \mathrm{~g} / \mathrm{kg}$ for protein without lysine supplementation where the diet was based on barley protein, and increased gradually to $53 \mathrm{~g} / \mathrm{kg} \mathrm{CP}$ with lysine supplmentation, so that lysine levels were low in comparison to ideal protein composition.

Lysine supplementation in the diet decreased urea excretion $\mathrm{g} / \mathrm{kgW}^{0.75} / \mathrm{d}$, and the regression equation for urea excretion as a function of crystalline lysine lysine was found to be:

$0.986(\mathrm{SE} 0.0403)-0.072(\mathrm{SE} 0.0212) * \mathrm{X}, \mathrm{R}^{2}=$ 0.434

$(\mathrm{X}=$ lysine supplement $\mathrm{g} / \mathrm{kg}$ ). The corresponding equation for liquid source was

$0.996(\mathrm{SE} 0.050)-0.074(\mathrm{SE} 0.0278) * \mathrm{X}, \mathrm{R}^{2}=$ 0.176 .

If the diet is kept constant in other nutritive factors but its amino acid composition changes as in this study, urinary $\mathrm{N}$ excretion alone can be assumed to reflect total protein utilization (Low et al. 1980). The major end product of amino acid catabolism in pigs is urea, the production of which reflects amino acid catabolism more closely than total urinary $\mathrm{N}$ excretion (EGGUM 1973, FULLER and WANG 1987).

In this study the coefficient of variation in urinary urea- $\mathrm{N}$ excretion was 0.209 , substantially higher than that of urinary $\mathrm{N}$ which was 0.109 . This may indicate decomposition of urea between collections despite acidification of the urine. In the liquid lysine source there may be some residual 


\section{Nitrogen retention}
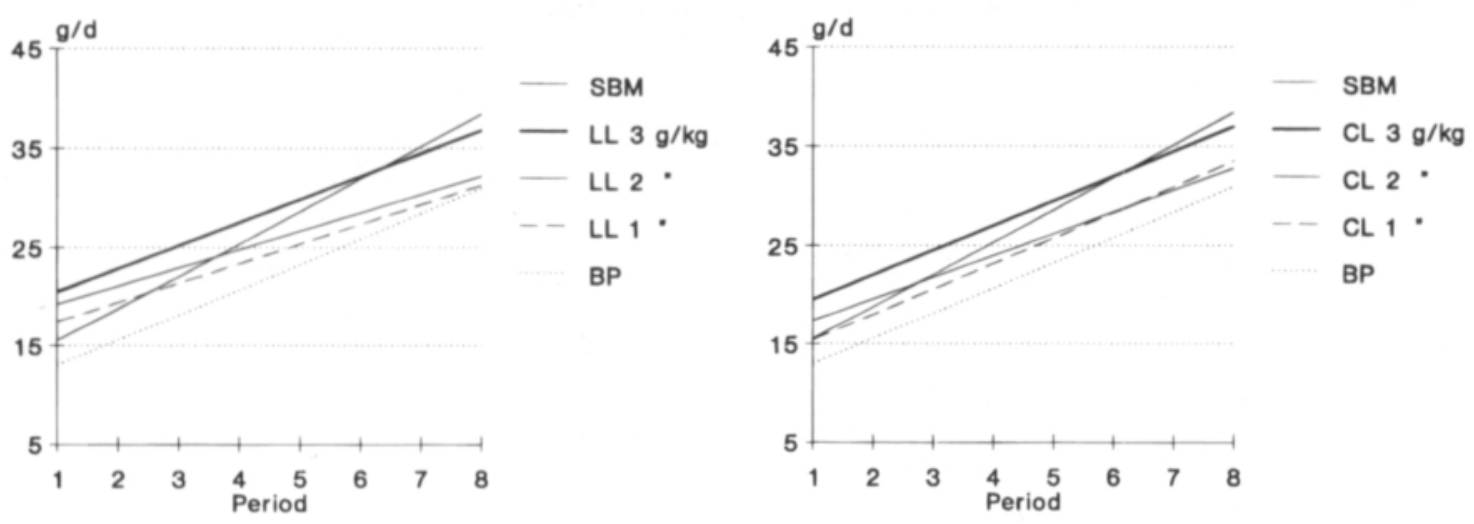

Nitrogen retention / absorption
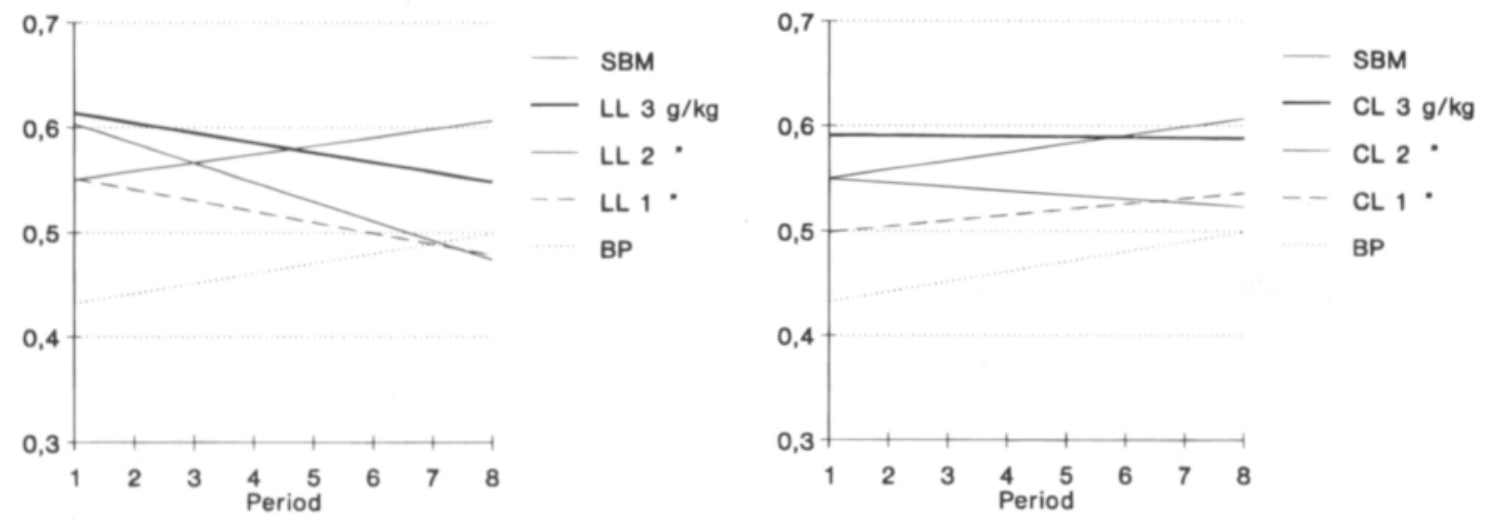

Fig. 1. Nitrogen retention and nitrogen retention in relation to absorption of nitrogen in pigs at different experimental periods. $\mathrm{LL}=$ liquid lysine, $\mathrm{CL}=$ crystalline lysine form.

nitrogenous material from the fermentation of the molasses, and crude protein from the microbial cells, which may also increase the variation. FULLER et al. (1987) found in different studies with growing pigs that 0.95 of urinary $\mathrm{N}$ excreted above $\mathrm{N}$ equilibrium is typically urea. In this study the ratio of the urinary urea- $\mathrm{N}$ of the total urinary $\mathrm{N}$ excretion was 0.79 . A tendency to a quadratic responce of urea- $\mathrm{N}$ in relation to total urinary- $\mathrm{N}$ excretion $(\mathrm{P}<0.07)$ with lysine was noticed, diets with $7.5 \mathrm{~g}$ lysine $/ \mathrm{kg}$ showed the lowest ratio.

Increasing increments of lysine up to $8.5 \mathrm{~g} / \mathrm{kg}$ showed a linear response of improved protein util- ization without reaching a plateau according to the parameters measured. The inflection point is at a higher concentration of lysine for pigs with improved genetical strain. HANRAHAN (1989) found the plateau region of lysine response as high as the $11 \mathrm{~g} / \mathrm{kg}$ increment when daily gain and feed conversion were the criteria. There was a continued improvement in backfat reduction and increased lean meat content in pigs up to lysine concentration higher than that which gave the maximal growth response. However, Yen et al. (1986) achieved the maximal growth and carcass response at the same lysine concentration. The pigs in this study were 
castrated males, but in many investigations maximum response was found in higher lysine levels for gilts or boars. The pigs in the present study were of high improved strain having a high potential for lean deposition which is indicated by the high daily gain.

The conclusion is that the supply of a well balanced protein based on the use of reasonable quantities of synthetic pure lysine reduces the total protein requirement due to the improved efficiency of protein utilization by bringing the pattern of ingested amino acids close to the needs of the pigs. Barley protein fortified with lysine could be substituted for a major proportion of the protein of soybean meal without adverse effect on $\mathrm{N}$-metabolism criteria of the pig. No difference was noticed in response of protein utilization to the form of lysine sources, the liquid form was as efficient as crystalline.

\section{References}

ARC 1981. The Nutrient requirements of farm livestock. Agricultural Research Council. Commonwealth Agricultural Bureaux, Slough.

Beker, M.E., Wiestur, U.E., Latsars, A.A., Mezhinya, G.R. \& PABERZS, A.O. 1971. Verfahren zur Herstellung des Futterkonzentrates von L-Lysin. Institut Mikrobiologii imeni A. Kirhensteina Akademii Nauk Latvijskoi SSR. Pat. 93704.

Berschauer, F., Gaus, G. \& Menke, K.H. 1980. Effect of body weight on efficiency of utilization of energy and protein in pigs. Proc. 8th Symp. on Energy Metabolism, Cambridge. EAAP Publ. 26: 101-105.

Fuller, M.F, Livingstone, R.M., BAird, B.A. \& AtKinson, T. 1979 a. The optimal amino acid supplementation of barley for the growing pig. 1. Responce of nitrogen metabolism to progressive supplementation. $\mathrm{Br}$. J. Nutr. 41: 321-331.

-, Mennie, I. \& Crofts, R.M.T. 1979 b. The optimal amino acid supplementation of barley for the growing pig. 1. Optimal additions of lysine and threonine for growth. Br. J. Nutr. 41: 321-331.

-, WANG, T.C. 1987. Amino acid requirements of the growing pig. In Manipulating Pig Production. p. 97-111. Australasian Pig Science Association. Werribee, Australia.

-, Wood, J., Brewer, A.C., Pennie, K. \& Mac William, R. 1986. The responses of growing pigs to dietary lysine, as free lysine hydrochloride or in soy-bean meal, and the influence of food intake. Anim. Prod. 43: 477-484.

Hanrahan, T.J. 1989. The response of growing pigs to lysine. The Feed Compounder 7: 32-39.

JusT, A. 1982. The net energy value of crude catabolized protein for growth in pigs. Livestock Prod. Sci. 9: 349360.

Linko, R., LapVeteläInen, A., LaAKso, P. \& Kallio, H. 1989. Protein composition of a high-protein barley flour and barley grain. Cereal Chem. 66: 478-482.

Low, A.G. \& Pittman, R.J. 1979. Responses of growing male pigs to practical diets supplemented with amino acids. Anim. Prod. 28: 435-436.

-, PitTMAn, R.J. \& FulFord, R.J. 1980. Studies on the optimum amino acid composition of practical diets for growing pigs using changeover nitrogen balance method. Proc. EAAP Symp. on Protein Metabolism and Nutrition. p. 680-687. Braunschweig.

NĂSI, M. 1984. Nutritive value and metabolic effects of whey protein concentrate and hydrolysed lactose for growing pigs. J. Agric. Sci. Finl. 56: 227-238.

- 1988. Evaluating barley feed fractions from integrated ethanol-starch production in diets of ruminants. J. Agric. Sci. Finl. 60: 701-709.

- 1989. Barley feed fractions from integrated ethanolstarch process in diets of pigs. J. Agric. Sci. Finl. 61: $441-450$.

SNedecor, G.W. \& Cochran, W.G. 1963. Statistical methods. 7th ed. p. 597. The Iowa State University Press, Ames, Iowa. USA.

Thorbek, G., Chwalibog, A. \& HenKel, S. 1984. Nitrogen and energy metabolism in pigs of Danish Landrace from 20 to $120 \mathrm{~kg}$ live weight. Norm for protein and energy requirements for maintenance and growth. Ber. Stat. Husbyrbr. fors. 563: 1-114.

WANG, T.C. \& FulleR, M.F. 1989. The optimum dietary amino acid pattern for growing pigs. 1. Experiments by amino acid deletion. Br. J. Nutr. 62: 77-89.

Yen, H.T., Cole, D.J.A. \& Lewis, D. 1986. Amino acid requirements of growing pigs. 7. The response of pigs from 25 to $55 \mathrm{~kg}$ live weight to dietary ideal protein. Anim. Prod. 43: 141-154.

\section{Manuscript received October 1991}

\section{Matti Näsi}

University of Helsinki

Department of Animal Science

SF-00710 Helsinki, Finland 


\title{
SELOSTUS
}

\section{Nestemäisen ja kiteisen lysiinin vaikutus ohra-ohravalkuaisdieetillä olevien lihasikojen valkuaisen hyväksikäyttöön}

\author{
MATTI NÄSI \\ Helsingin yliopisto
}

Tutkimuksessa selvitettiin nestemäisen ja kiteisen puhtaan lysiinin lisåysten vaikutusta ohra-ohravalkuaisdieetillä ruokittujen lihasikojen valkuaisen hyväksikäyttöön. Tutkimus tehtiin $8 \times 8$ latinalaisena neliönä $30-100 \mathrm{~kg}$ elopainoisilla lihasioilla. Rehun raakavalkuaispitoisuus oli kaikissa kahdeksassa koerehuseoksessa sama $160 \mathrm{~g} / \mathrm{kg}$. Lysiinitäydennykset olivat 1,2 ja $3 \mathrm{~g} / \mathrm{kg}$ puhtaana lysiinină kumpaakin lysiinilähdettă kăytettăessă. Seosten kokonaislysiinipitoisuudet olivat $5.5 \mathrm{~g} / \mathrm{kg}$ tăydentämättömăssa seoksessa ja vastaavasti $6.5,7.5$ ja $8.5 \mathrm{~g} / \mathrm{kg}$ täydennetyissä rehuseoksissa. Vertailuseoksena oli soija-ohraseos, jossa oli $7.4 \mathrm{~g} / \mathrm{kg}$ lysiiniả. Lysiinilisäyksellä verrattuna tảydentămăttőmảăn dieet- tiin oli merkitsevä vaikutus moniin valkuaisen hyvăksikäyttöä kuvaaviin tunnuslukuihin. Lysiinin lisääminen paransi lineaarisesti typen pidättymistä ja valkuaisen biologista arvoa sekä văhensi virtsan typen ja urean eritystä. Sikojen typpitase parani keskimăărin $10 \%$ lisăttyă lysiiniă $\mathrm{g} / \mathrm{kg}$ kohti. Lysiinilăhteiden välillä ei ollut eroa. Soija-ohraseoksella ruokittujen sikojen ja vastaavalla lysiintasolla olleiden ohra-ohravalkuaisella ruokittujen sikojen valkuaisen hyvăksikäytössä ei ollut eroja. Tutkimuksen tulosten mukaan lysiinitäydennyksellä voitiin viljavalkuaisen biologista arvoa parantaa samaan tasoon kuin viljan ja soijan seos. 